\title{
SYNTHESIS AND ANTIMICROBIAL ACTIVITY OF SOME NEW QUINOLINE AND ${ }^{1}$ H-PYRAZOLO[3,4-b]QUINOLINE DERIVATIVES
}

\author{
Monir A-S. Amin ${ }^{1}$, Mohammed M. Ismail ${ }^{2}$, Saber E-S. Barakat ${ }^{1}$, Ashraf A-A. Abdul-Rahman ${ }^{1}$, \\ Ashraf H. Bayomi ${ }^{1}$ and Kamal M.A. El-Gamal ${ }^{1}$ \\ ${ }^{1}$ Department of Pharmaceutical Chemistry, Faculty of Pharmacy, Al-Azhar University, \\ Cairo, Egypt \\ ${ }^{2}$ Department of Organic Chemistry, Faculty of Pharmacy, Cairo University, Cairo, Egypt
}

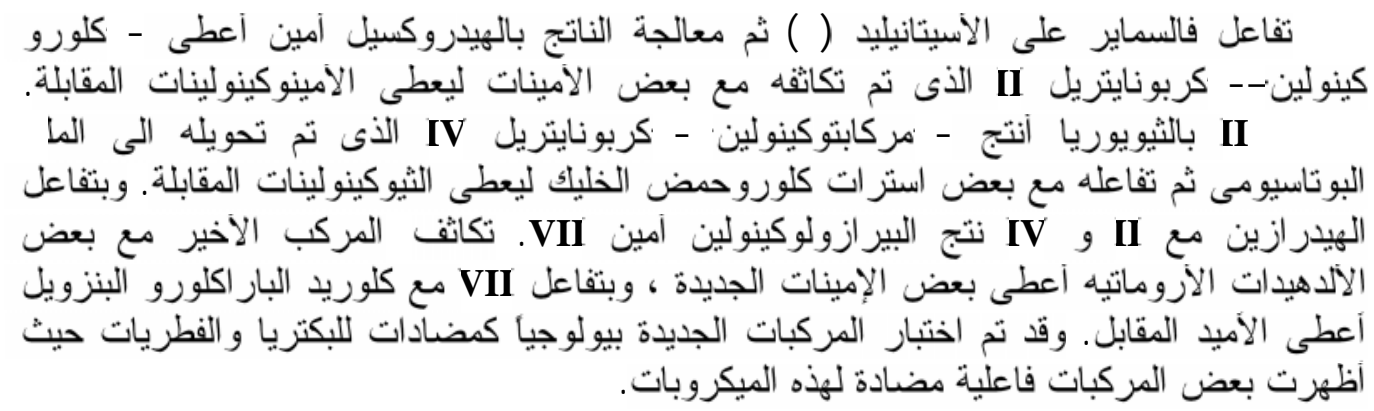

Vilsmeier formylation of acetanilide I followed by treatment with hydroxylamine produced 2-chloroquinoline-3-carbonitrile II that was condensed with different amines to give 2substituted aminoquinolines-3-carbonitriles III. Treatment of II with thiourea yielded 2mercaptoquinoline-3-carbonitrile $\mathbf{I V}$, which was converted to its potassium salt $\boldsymbol{V}$ that was condensed with some chloroacetate esters to produce 2-substituted thioquinoline-3carbonitriles VI. Hydrazinolysis of II or IV gave 1H-pyrazolo[3,4-b]quinolin-3-ylamine VII. Condensation of VII with different aryl aldehydes resulted in the corresponding imines VIII. Treatment of VII with p-chloro-benzoyl chloride afforded the amide IX. Some of the synthesized compounds were evaluated for their antibacterial and antifungal activity.

\section{INTRODUCTION}

The quinoline ring system represents the building block of many biologically active compounds that possess antimalarial, ${ }^{1-4}$ antiamebic, ${ }^{5,6}$ bronchodilator, ${ }^{7,8}$ antihypertensive, ${ }^{9-11}$, anti-inflammatory, ${ }^{12}$ antidepressant, ${ }^{13}$ and Scr kinase inhibitory action. ${ }^{14}$ In addition many pyrazoloquinolines have been reported to possess antibacterial, antifungal, and antiviral. ${ }^{15,16}$ On the other hand, 2chloroquinoline-3-carbonitrile (II) is a good starting material for the preparation of different quinoline derivatives. ${ }^{17}$ Accordingly, it was decided to prepare (II) as a versatile synthon from which some new 2-substituted quinoline3-carbonitrile derivatives [(III) and (VI)] and some new pyrazoloquinolines [(VIII) and (IX)] could be prepared as shown in Scheme (1) with the aim to evaluate their antimicrobial action.

\section{EXPERIMENTAL}

All melting points were carried on a Gallenkamp melting point apparatus and are uncorrected. The infrared spectra were recorded on Brucker-Vector-22-FT-IR Spectrophotometer using the potassium bromide disc technique. The ${ }^{1} \mathrm{HNMR}$ spectra were recorded on Varian-Gemini-200-MHzSpectrophotometer using $\mathrm{CDCl}_{3}$ or $\mathrm{DMSO}_{-} \mathrm{d}_{6}$ as solvents and TMS as internal reference. The chemical shift values were recorded in $\delta \mathrm{ppm}$ downfield the TMS signal. The Mass spectra were recorded on $\mathrm{AZH}-\mathrm{Ph}-\mathrm{AR}-\mathrm{XO}_{2}$ Mass spectrometer. Elemental analyses were 


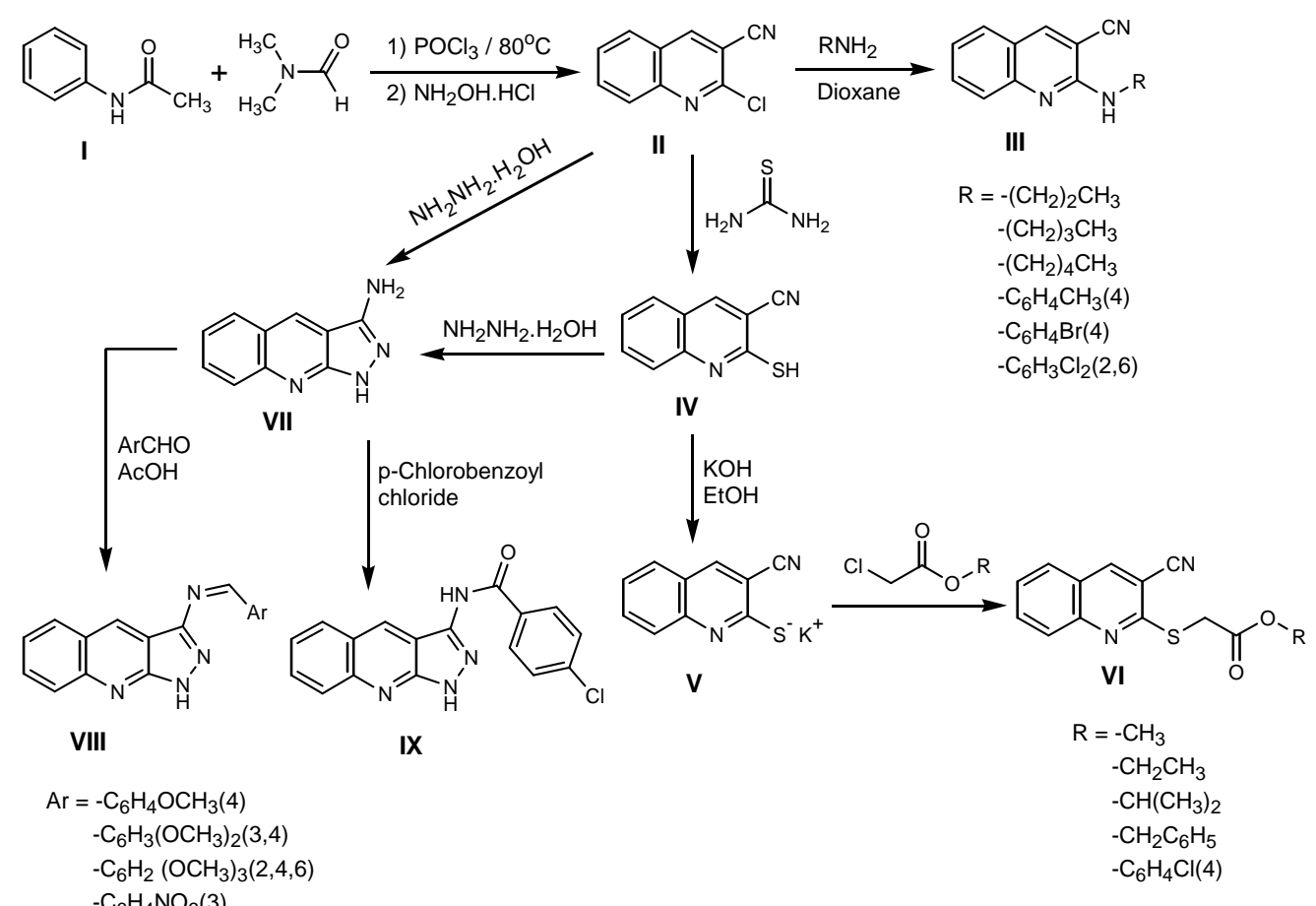

Scheme 1

performed on a $\mathrm{CHN}$ analyzer. All analyses were preformed at the Microanalytical Unit of Cairo University, Cairo, Egypt.

Following reported procedures, 2-chloroquinoline-3-carbonitrile (II) ${ }^{16}$ 2-mercaptoquinoline-3-carbonitrile (IV $)^{21}$ and $1 \mathrm{H}-$ pyrazolo[3,4-b]quinolin-3-ylamine (VII) ${ }^{16}$ were prepared.

\section{2-Substituted aminoquinoline-3- carbonitriles (IIIa-f)}

A mixture of 2-chloroquinoline-3carbonitrile (II) $(1.89 \mathrm{~g}, 0.01 \mathrm{~mol})$ and alkyl amine or aryl amine $(0.01 \mathrm{~mol})$ in dry dioxane $(50 \mathrm{ml})$ was refluxed overnight then the mixture was allowed to cool. The separated solid was collected, filtered, dried, washed with ethanol and crystallized from absolute ethanol (Table 1).

\section{Potassium salt of 2-mercaptoquinoline-3- carbonitnile (V)}

2-Mercaptoquinoline-3-carbonitrile (IV) $(1.86 \mathrm{~g}, 0.01 \mathrm{~mol})$ was dissolved in absolute ethanol $(50 \mathrm{ml})$ and then treated with alcoholic potassium hydroxide $(0.56 \mathrm{~g}, 0.01 \mathrm{~mol})$. The reaction mixture was stirred for an hour and the resulting solid was filtered, washed with diethyl ether and dried. m.p, $>300^{\circ}$, Yield, 95\%.

\section{3-Cyano-2-alkoxy / aryloxycarbonylmethyl- thioquinolines (VIa-e)}

A mixture of potassium salt of 2mercaptoquinoline-3-carbonitrile (V) (2.24 g, $0.01 \mathrm{~mol})$ and the appropriate chloroacetate esters $(0.01 \mathrm{~mol})$ in dimethylformamide $(30 \mathrm{ml})$ was heated for four hours at $100^{\circ}$. The reaction mixture was poured onto ice-cooled water and the solid produced was filtered, dried and crystallized from ethanol (Table 2).

\section{H-Pyrazolo[3,4-b]quinolin-3-ylamine (VII) (New Method)}

To a stirred suspension of 2-mercaptoquinoline-3-carbonitrile (IV) (14.4 g, 0.078 mol) in absolute ethanol $(100 \mathrm{ml})$ was added hydrazine hydrate $(20 \mathrm{ml}, 80 \%)$. The mixture was stirred at reflux for 12 hours and then cooled. The resulting solid was filtered boiled with water and filtered. The crude product was dried and recrystallized from ethanol. m.p, $>300^{\circ}$, Yield, $10.7 \mathrm{~g}, 75 \%$, as the reported. ${ }^{23}$

IR $\left(\mathrm{KBr}, \mathrm{cm}^{-1}\right): 3385.2,3306.6,3178.3$ $\left(\mathrm{NH}_{2}, \mathrm{~N}-\mathrm{H}\right), 1641.2,1577.6,1483.6(\mathrm{C}=\mathrm{C}$, $\mathrm{C}=\mathrm{N}$ ). 
Table 1: Physical data and elemental analysis of 2-substituted aminoquinoline-3-carbonitrile (IIIa-f).

\begin{tabular}{|c|c|c|c|c|c|c|c|}
\hline \multirow{2}{*}{$\begin{array}{l}\text { Comp. } \\
\text { (III) }\end{array}$} & \multirow[t]{2}{*}{$\mathrm{R}$} & \multirow[t]{2}{*}{ m.p. ${ }^{\circ}$} & \multirow{2}{*}{$\begin{array}{c}\text { Yield } \\
\%\end{array}$} & \multirow{2}{*}{$\begin{array}{l}\text { M. Formula/ } \\
\text { M. Weight }\end{array}$} & \multicolumn{3}{|c|}{$\begin{array}{c}\text { Elemental Analysis \% } \\
\text { Calcd./Found }\end{array}$} \\
\hline & & & & & $\mathrm{C}$ & $\mathrm{H}$ & $\mathrm{N}$ \\
\hline $\mathbf{a}$ & $-\left(\mathrm{CH}_{2}\right)_{2} \mathrm{CH}_{3}$ & $100-101$ & 80 & $\begin{array}{c}\mathrm{C}_{13} \mathrm{H}_{13} \mathrm{~N}_{3} \\
211.26\end{array}$ & $\begin{array}{l}73.91 \\
73.45 \\
\end{array}$ & $\begin{array}{l}6.20 \\
5.80 \\
\end{array}$ & $\begin{array}{l}19.89 \\
20.00 \\
\end{array}$ \\
\hline b & $-\left(\mathrm{CH}_{2}\right)_{3} \mathrm{CH}_{3}$ & $90-91$ & 85 & $\begin{array}{c}\mathrm{C}_{14} \mathrm{H}_{15} \mathrm{~N}_{3} \\
225.29 \\
\end{array}$ & $\begin{array}{l}74.64 \\
74.52 \\
\end{array}$ & $\begin{array}{l}6.71 \\
6.76 \\
\end{array}$ & $\begin{array}{l}18.65 \\
18.42 \\
\end{array}$ \\
\hline $\mathbf{c}$ & $-\left(\mathrm{CH}_{2}\right)_{4} \mathrm{CH}_{3}$ & $85-86$ & 85 & $\begin{array}{c}\mathrm{C}_{15} \mathrm{H}_{17} \mathrm{~N}_{3} \\
239.32\end{array}$ & $\begin{array}{l}75.28 \\
75.30 \\
\end{array}$ & $\begin{array}{l}7.16 \\
7.15 \\
\end{array}$ & $\begin{array}{l}17.56 \\
17.32 \\
\end{array}$ \\
\hline d & $-\mathrm{C}_{6} \mathrm{H}_{4} \mathrm{CH}_{3}(4)$ & $125-126$ & 40 & $\begin{array}{c}\mathrm{C}_{17} \mathrm{H}_{13} \mathrm{~N}_{3} \\
259.31\end{array}$ & $\begin{array}{l}78.74 \\
78.84\end{array}$ & $\begin{array}{l}5.05 \\
5.06\end{array}$ & $\begin{array}{l}16.20 \\
16.22\end{array}$ \\
\hline e & $-\mathrm{C}_{6} \mathrm{H}_{4} \mathrm{Br}(4)^{22}$ & $115-116$ & 80 & $\begin{array}{c}\mathrm{C}_{16} \mathrm{H}_{10} \mathrm{BrN}_{3} \\
324.17\end{array}$ & $\begin{array}{l}59.28 \\
59.57\end{array}$ & $\begin{array}{l}3.11 \\
3.54\end{array}$ & $\begin{array}{l}12.96 \\
12.32\end{array}$ \\
\hline $\mathbf{f}$ & $-\mathrm{C}_{6} \mathrm{H}_{3} \mathrm{Cl}_{2}(2,6)$ & $135-137$ & 70 & $\begin{array}{c}\mathrm{C}_{16} \mathrm{H}_{9} \mathrm{Cl}_{2} \mathrm{~N}_{3} \\
314.17 \\
\end{array}$ & $\begin{array}{l}61.17 \\
61.11 \\
\end{array}$ & $\begin{array}{l}2.89 \\
3.17 \\
\end{array}$ & $\begin{array}{l}13.38 \\
13.12 \\
\end{array}$ \\
\hline
\end{tabular}

III-a, IR (KBr, $\left.\mathrm{cm}^{-1}\right): 3391(\mathrm{~s}, \mathrm{~N}-\mathrm{H}), 2218(\mathrm{~s}, \mathrm{C} \equiv \mathrm{N}), 1620-1541$ (s, C=N, C=C, aromatic). ${ }^{1} \mathrm{HNMR}$ $\left(\mathrm{CDCl}_{3}, \delta \mathrm{ppm}\right): 8.16$ (s, 1H, H-4), 7.66-7.63 (m, 3H, H-5, H-8, H-7), 7.27-7.23 (t, 1H, H-6), 5.25 (b.s, 1H, N-H), 3.63-3.53 (t, 2H, NH-C $\underline{H}_{2}$ ), 1.83-1.63 (sex, $2 \mathrm{H}_{,} \mathrm{CH}_{2}-\mathrm{CH}_{2} \mathrm{CH}_{3}$ ), 1.07-0.99 (t, $\left.3 \mathrm{H}, \mathrm{CH}_{2}-\mathrm{CH}_{3}\right) . \mathrm{MS}$ (m/z, abund.\%): 211 (30.3, M), $196\left(28.6, \mathrm{M}-\mathrm{CH}_{3}\right), 182\left(100, \mathrm{M}_{-} \mathrm{C}_{2} \mathrm{H}_{5}\right), 169$ (91.6, $\left.\mathrm{M}-\mathrm{CH}_{2} \mathrm{CHCH}_{3}\right), 153\left(62.6, \mathrm{M}-\mathrm{NHC}_{3} \mathrm{H}_{7}\right), 127$ (23.9, $\left.\mathrm{M}-\mathrm{NHC}_{3} \mathrm{H}_{7} / \mathrm{CN}\right)$

III-d, IR (KBr, cm ${ }^{-1}$ ): 3449.8 (b, -N-H-), 3055.3 (s, C-H aromatic), 2953 (s, CH, aliphatic), 2211.9 (s, $\mathrm{C} \equiv \mathrm{N}), 1620.5$ (s, $\mathrm{C}=\mathrm{C}$ aromatic). ${ }^{1} \mathrm{HNMR}\left(\mathrm{CDCl}_{3}, \delta \mathrm{ppm}\right): 8.56$ (s, $\left.1 \mathrm{H}, \mathrm{H}-4\right), 8.00-7.86(\mathrm{~m}, 3 \mathrm{H}$, H-5, H-7, H-8), 7.58-7.57(d, 2H, H2-,H-6 of tolyl), 7.55-7.54(t,1H, H-6), 7.53-7.52 (s, 1H, NH), 7.51(d, 2H, H-3, H-5 of tolyl), 3.59 (s, 3H, C-H, aliphatic). MS (m/z, abund.\%): 259 (37.3, $\mathrm{M}^{+}$), 258 (66.7, M-H), 168 (100, M- $\left.\mathrm{C}_{6} \mathrm{H}_{4} \mathrm{CH}_{3}\right), 153$ (36.7, M-NHC $\left.\mathrm{H}_{6} \mathrm{H}_{4} \mathrm{H}_{3}\right), 127$ (33.3, M$\left.\mathrm{NHC}_{6} \mathrm{H}_{4} \mathrm{CH}_{3} / \mathrm{CN}\right)$.

III-e, ${ }^{1} \mathrm{HNMR}\left(\mathrm{CDCl}_{3}, \delta \mathrm{ppm}\right): 8.36$ (s, $\left.1 \mathrm{H}, \mathrm{H}-4\right), 8.25$ (s, 1H, NH), 7.84-7.65 (m, 5H, H-5, H-8, H-7 \& $\mathrm{H}_{3,5}$ of phenyl), 7.43-7.40 (t,1H, H-6), 7.26-7.23 (d, 2H, $\mathrm{H}_{2,6}$ of phenyl). MS (m/z, abund.\%): 323/325 (51.3/56.7, $\left.\mathrm{M}^{+}\right), 243(53.8, \mathrm{M}-\mathrm{HBr}), 216$ (14.1, M-HBr, HCN), 153 (37.3, M$\left.\mathrm{NHC}_{6} \mathrm{H}_{4} \mathrm{Br}\right), 127$ (31.3, M-NHC $\left.6 \mathrm{H}_{4} \mathrm{Br} / \mathrm{CN}\right)$. 
Table 2: The physical data and elemental analysis of (3-Cyano-2-alkoxy/aryloxy carbonylmethylthioquinolines (VIa-e).

\begin{tabular}{|c|c|c|c|c|c|c|c|}
\hline \multirow{2}{*}{$\begin{array}{c}\text { Comp. } \\
\text { (VI) }\end{array}$} & \multirow{2}{*}{$\mathrm{R}$} & \multirow{2}{*}{ M.P. } & \multirow{2}{*}{$\begin{array}{c}\text { Yield } \\
\%\end{array}$} & $\begin{array}{c}\text { M. Formula/ } \\
\text { M. Weight }\end{array}$ & \multicolumn{3}{|c|}{$\begin{array}{c}\text { Elemental Analysis \% } \\
\text { Calcd./Found }\end{array}$} \\
\cline { 5 - 8 } & & & & & $\mathrm{C}$ & $\mathrm{H}$ & $\mathrm{N}$ \\
\hline a & $-\mathrm{CH}_{3}$ & $129-130$ & 80 & $\mathrm{C}_{13} \mathrm{H}_{10} \mathrm{~N}_{2} \mathrm{O}_{2} \mathrm{~S}$ & 60.45 & 3.90 & 10.85 \\
& & & & 258.30 & 60.31 & 3.94 & 10.37 \\
\hline b & $-\mathrm{CH}_{2} \mathrm{CH}_{3}$ & $120-121$ & 85 & $\mathrm{C}_{14} \mathrm{H}_{12} \mathrm{~N}_{2} \mathrm{O}_{2} \mathrm{~S}$ & 61.75 & 4.44 & 10.29 \\
& & & & 272.32 & 62.74 & 4.82 & 10.39 \\
\hline c & $-\mathrm{CH}\left(\mathrm{CH}_{3}\right)_{2}$ & $180-182$ & 70 & $\mathrm{C}_{15} \mathrm{H}_{14} \mathrm{~N}_{2} \mathrm{O}_{2} \mathrm{~S}$ & 62.92 & 4.93 & 9.78 \\
& & & 286.35 & 62.48 & 4.69 & 9.89 \\
\hline d & $-\mathrm{CH}_{2} \mathrm{C}_{6} \mathrm{H}_{5}$ & $188-190$ & 60 & $\mathrm{C}_{19} \mathrm{H}_{14} \mathrm{~N}_{2} \mathrm{O}_{2} \mathrm{~S}$ & 68.24 & 4.22 & 8.38 \\
& & & & 334.39 & 68.10 & 4.30 & 8.75 \\
\hline e & $-\mathrm{C}_{6} \mathrm{H}_{4} \mathrm{Cl}(4)$ & $200-202$ & 65 & $\mathrm{C}_{18} \mathrm{H}_{11} \mathrm{ClN}_{2} \mathrm{O}_{2} \mathrm{~S}$ & 60.93 & 3.12 & 7.90 \\
& & & \multicolumn{7}{|c|}{354.81} & 60.86 & 3.06 & 8.35 \\
\hline
\end{tabular}

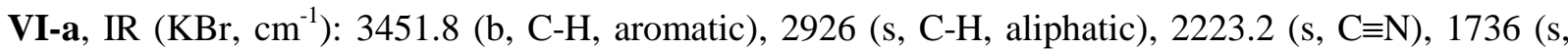
$\mathrm{C}=\mathrm{O}) .{ }^{1} \mathrm{HNMR}\left(\mathrm{CDCl}_{3}, \delta \mathrm{ppm}\right): 8.36(\mathrm{~s}, 1 \mathrm{H}, \mathrm{H}-4), 7.94-7.76$ (m, 3H, H-7, H-5 and H-8) 7.58-

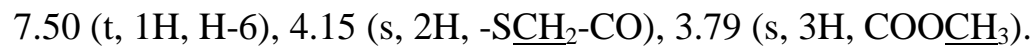

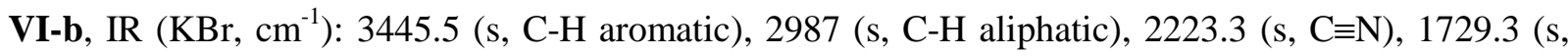

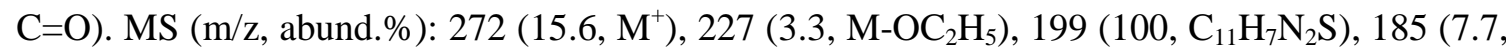
$\left.\mathrm{M}-\mathrm{CH}_{2} \mathrm{COOC}_{2} \mathrm{H}_{5}\right), 153$ (62.6, cyanoquinoline cation), $126\left(53.3, \mathrm{C}_{9} \mathrm{H}_{4} \mathrm{~N}\right), 76\left(23.6, \mathrm{C}_{6} \mathrm{H}_{4}\right)$.

VI-c, IR (KBr, cm ${ }^{-1}$ ): 3270.3 (s, C-H aromatic), 2978 (s, C-H aliphatic), 2222.2 (s, C=N), 1728 (s, $\mathrm{C}=\mathrm{O}$ ). ${ }^{1} \mathrm{HNMR}$ (DMSO, $\delta$ ppm): 9.21 (s, 1H, H-4), 8.11-8.04 (d, 1H, H-8), 7.91-7.83 (t, 1H, C7), 7.68-7.60 (t, 1H, H-6), 7.52 (bs, $1 \mathrm{H}, \mathrm{H}-5), 4.07$ (s, 2H, $-\mathrm{SCH}_{2}-\mathrm{CO}$ ), 2.0 (septet, $1 \mathrm{H}$, isopropyl), $0.89-0.86$ (d, $6 \mathrm{H}$, two $\underline{\mathrm{CH}}_{3}$ of isopropyl).

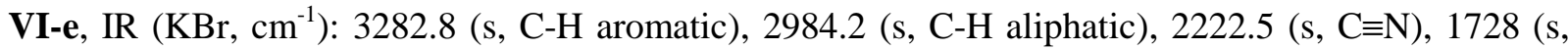
$\mathrm{C}=\mathrm{O}$ ). ${ }^{1} \mathrm{HNMR}$ (DMSO, $\delta \mathrm{ppm}$ ): 9.39 (s, $\left.1 \mathrm{H}, \mathrm{H}-4\right), 8.11-8.09$ (m, $\left.1 \mathrm{H}, \mathrm{H}-8\right), 8.07-7.81$ (m, 3H, C7, H-5, H-6), [7.56-7.51 (d, 2H), 7.38-7.23 (d, 2H) p-disubstituted phenyl), 3.38 (s, 2H, $-\mathrm{SCH}_{2}-$ CO). MS (m/z, abund.\%): 354/356 (7.9/2.8, M $\left.{ }^{+}\right), 227\left(100, \mathrm{M}_{-} \mathrm{OC}_{6} \mathrm{H}_{4} \mathrm{Cl}\right), 199$ (23.5, M$\left.\mathrm{OCOC}_{6} \mathrm{H}_{4} \mathrm{Cl}\right), 172\left(14.7, \mathrm{M}-\mathrm{OCOC}_{6} \mathrm{H}_{4} \mathrm{Cl}, \mathrm{HCN}\right), 155$ (20.3, M-S=CHCOOC $\left.\mathrm{H}_{4} \mathrm{Cl}\right), 127$ (7.1, $\mathrm{C}_{9} \mathrm{H}_{4} \mathrm{~N}^{+}$). 
Substituted Arylidene-(1H-pyrazolo[3,4b]quinolin-3-yl)-amines (VIII a-e)

To solution of 1H-pyrazolo[3,4-b]quinolin-3-ylamine (VII) (1.84 g, 0.01 mole) in ethanol $(25 \mathrm{ml})$ containing $0.5 \mathrm{ml}$ of acetic acid, the appropriate aldehyde ( 0.01 mole) was added and the mixture was heated under reflux for 2 hours. The reaction mixture was concentrated and allowed to cool. The separated solid was filtered and recrystallized from ethanol (Table 3).

Table 3: The physical data and elemental analysis of arylidene-1H-pyrazolo[3,4-b]quinolin-3-yl)amine derivatives (VIIIa-e).

\begin{tabular}{|c|c|c|c|c|c|c|c|}
\hline \multirow{2}{*}{$\begin{array}{l}\text { Comp. } \\
\text { VIII }\end{array}$} & \multirow[t]{2}{*}{$\mathrm{Ar}$} & \multirow[t]{2}{*}{ M.P. } & \multirow{2}{*}{$\begin{array}{c}\text { Yield } \\
\%\end{array}$} & \multirow{2}{*}{$\begin{array}{l}\text { M.Formula } \\
\text { M. Weight }\end{array}$} & \multicolumn{3}{|c|}{$\begin{array}{c}\text { Elemental Analysis \% } \\
\text { (Calcd./Found) }\end{array}$} \\
\hline & & & & & $\mathrm{C}$ & $\mathrm{H}$ & $\mathrm{N}$ \\
\hline $\mathbf{a}$ & $\mathrm{C}_{6} \mathrm{H}_{4} \mathrm{OCH}_{3}(4)$ & $230-232$ & 70 & $\begin{array}{c}\mathrm{C}_{18} \mathrm{H}_{14} \mathrm{~N}_{4} \mathrm{O} \\
302.33 \\
\end{array}$ & $\begin{array}{l}71.51 \\
71.45 \\
\end{array}$ & $\begin{array}{l}4.67 \\
4.96 \\
\end{array}$ & $\begin{array}{l}18.53 \\
17.55 \\
\end{array}$ \\
\hline b & $\mathrm{C}_{6} \mathrm{H}_{3}\left(\mathrm{OCH}_{3}\right)_{2}(3,4)$ & $240-241$ & 65 & $\begin{array}{c}\mathrm{C}_{19} \mathrm{H}_{16} \mathrm{~N}_{4} \mathrm{O}_{2} \\
332.36 \\
\end{array}$ & $\begin{array}{l}68.66 \\
67.88 \\
\end{array}$ & $\begin{array}{l}4.85 \\
5.11 \\
\end{array}$ & $\begin{array}{l}16.86 \\
16.50 \\
\end{array}$ \\
\hline c & $\mathrm{C}_{6} \mathrm{H}_{2}\left(\mathrm{OCH}_{3}\right)_{3}(2,4,6)$ & $195-196$ & 70 & $\begin{array}{c}\mathrm{C}_{20} \mathrm{H}_{18} \mathrm{~N}_{4} \mathrm{O}_{3} \\
362.38 \\
\end{array}$ & $\begin{array}{l}66.29 \\
67.00 \\
\end{array}$ & $\begin{array}{l}5.01 \\
5.00 \\
\end{array}$ & $\begin{array}{l}15.46 \\
15.52 \\
\end{array}$ \\
\hline d & $\mathrm{C}_{6} \mathrm{H}_{4} \mathrm{NO}_{2}(3)$ & $280-282$ & 73 & $\begin{array}{c}\mathrm{C}_{17} \mathrm{H}_{11} \mathrm{~N}_{5} \mathrm{O}_{2} \\
317.30 \\
\end{array}$ & $\begin{array}{l}64.35 \\
64.42 \\
\end{array}$ & $\begin{array}{l}3.49 \\
3.51 \\
\end{array}$ & $\begin{array}{l}22.07 \\
21.82 \\
\end{array}$ \\
\hline e & & $223-4$ & 80 & $\begin{array}{c}\mathrm{C}_{15} \mathrm{H}_{10} \mathrm{~N}_{4} \mathrm{~S} \\
378.33\end{array}$ & $\begin{array}{l}64.73 \\
64.64\end{array}$ & $\begin{array}{l}3.62 \\
4.35\end{array}$ & $\begin{array}{l}20.13 \\
19.72\end{array}$ \\
\hline
\end{tabular}

VIII-a, IR (KBr, cm ${ }^{-1}$ ): 3420 (broad, N-H), 3180 (s, C-H, aromatic), 2839 (s, C-H, aliphatic), 1610.2 (s, C=C, C=N), 1510 (s, C=C, C=N aromatic). ${ }^{1} \mathrm{H}$ NMR (DMSO, $\delta$ ppm): 13.37 (s, 1H, N-H pyrazolo.), 9.29 (s, 1H, -N=CH-), 9.21(s,1H, H-4), 8.23-8.19 (d, 1H, H-8), 8.12-8.07 (d, 2H, $\mathrm{H}_{2,6}$ of $p$-phenyl), 8.04-8.00 (d, 1H, H-5) 7.85-7.78 (t, 1H, H-7), 7.56-7.52 (t,1H, H-6), 7.18$7.14\left(\mathrm{~d}, 2 \mathrm{H}, \mathrm{H}_{3,5}\right.$ of $p$-phenyl), 3.89 (s, 3H, O-CH 3 ). $\mathrm{MS}$ (m/z, abund.\%): $302\left(94.7, \mathrm{M}^{+}\right), 301$ $(100, \quad \mathrm{M}-1), \quad 271 \quad\left(9.6, \quad \mathrm{M}-\mathrm{OCH}_{3}\right), \quad 184 \quad\left(2.6, \quad \mathrm{M}+2-\mathrm{CHC}_{6} \mathrm{H}_{4} \mathrm{OCH}_{3}\right) \quad 169 \quad(22.9, \quad \mathrm{M}-$ $\mathrm{NCHC}_{6} \mathrm{H}_{4} \mathrm{OCH}_{3}$ ), 142 (13.5, aziridinoquinoline cation).

VIII-d, ${ }^{1} \mathrm{H}$ NMR (DMSO, $\delta$ ppm): 13.65 (s, 1H, N-H pyrazolo), 9.53 (s, 1H, -N=CH-), 9.33 (s,1H, H4), 8.92 (s, 1H, H-2 of the phenyl), 8.54-7,78 (3d, m, 6H, H-4, H-5, H-6 of phenyl \& H-8, H-5, $\mathrm{H}-7$ of quinoline), 7.57-7.49 (t, 1H, H-6).

VIII-e, MS (m/z, abund.\%) $278(54 \%)\left(\mathrm{M}^{+}\right), 184$ (100\%) ([M+2]- $\left.\mathrm{C}_{5} \mathrm{H}_{4} \mathrm{~S}\right), 169$ (34.0\%) (M$\left.\mathrm{C}_{4} \mathrm{H}_{4} \mathrm{SCN}\right), 142$ (28.9\%) (aziridinoquinoline cation). 


\section{4-Chloro-N-(1H)-pyrazolo[3,4-b]quinolin-3- yl)-benzamide (IX)}

1H-Pyrazolo[3,4-b]quinolin-3-ylamine (VII) (1.84 g, $0.01 \mathrm{~mol})$ was suspended in dry pyridine; then $p$-chlorobenzoyl chloride (1.75 $\mathrm{g}, \quad 0.01 \mathrm{~mol}$ ) was added dropwise with continuous stirring at room temperature. The reaction mixture was stirred for 24 hour and was poured gradually while stirring onto icecold water. The separated solid, was filtered, washed with water, dried and crystallized from absolute ethanol.

m.p, $305^{\circ}$, Yield, 70\%. $\mathrm{C}_{17} \mathrm{H}_{11} \mathrm{ClN}_{4} \mathrm{O}$ (322.75), Calcd. (Found) C\% 63.26 (63.81), H\% 3.44 (4.17), N\% 17.36 (17.20).

${ }^{1} \mathrm{HNMR}\left(\mathrm{CDCl}_{3}, \delta \mathrm{ppm}\right): 13.29(\mathrm{~s}, 1 \mathrm{H}$, $\underline{\mathrm{NH}}$-pyrazole), $11.36(\mathrm{~s}, 1 \mathrm{H}, \mathrm{N}-\mathrm{H},-\mathrm{NHC}=\mathrm{O})$, 9.05 (s, 1H, H-4), 8.19-8.15 (d, 3H, H-8 \& H-2,6 of phenyl), 8.02-7.98 (d, 1H, H-5), 7.84-7.7.77 $(\mathrm{t}, 1 \mathrm{H}, \mathrm{H}-7), 7.69-7.7 .65\left(\mathrm{~d}, 2 \mathrm{H}, \mathrm{H}_{-3,5}\right.$ of phenyl), 7.52-7.45 (t, 1H, H-7). MS $(\mathrm{m} / \mathrm{z}$, abound.\%):- 322/324 (14.3/4.2 M $\left.\mathrm{M}^{+}\right), 141$ (35,6, aziridino-quinoline cation), $139 \quad(100$, $\left.\mathrm{ClC} 6 \mathrm{H}_{4} \mathrm{CO}^{+}\right), 111 / 113\left(37.8 / 11.4,{ }^{+} \mathrm{C}_{6} \mathrm{H}_{4} \mathrm{Cl}\right)$, $75\left(17.8,{ }^{+} \mathrm{C}_{6} \mathrm{H}_{3}\right)$.

\section{Antimicrobial Testing}

Staphylococcus aureus, Bacillus subtilis, Escherichia coli, Pseudomonas aeruginosa, and Candida albicans were obtained from stock culture collection of Faculty of Pharmacy (Boys), Al-Azhar University, Cairo. Ofloxacin was used as antibacterial standard and Nystatin as antifungal standard. Suspension of the above mentioned microorganisms were prepared by inoculating fresh stock cultures into separate broth tubes, each containing $7 \mathrm{ml}$ of nutrient broth (peptone, $0.3 \%$ and beef extract $0.3 \%$ ). The inoculated tubes were incubated at $37^{\circ}$ for 24 hours before use. 10-25 $\mathrm{mg}$ of each compound were dissolved in $2 \mathrm{ml}$ dimethylformamide with or without the aid of heat.

\section{Agar Diffusion Method $^{19}$}

Tells of nutrient agar in test tube each containing $15 \mathrm{ml}$ of nutrient agar sterilized by autoclaving at $121^{\circ}$ for 30 minutes were prepared and poured each in an empty sterile
Petri-dish $(15 \times 150 \mathrm{~mm})$, the depth of agar was approximately $6 \mathrm{~mm}$. The culture of each organism was spread with dry sterile swab on the surface of the previously prepared plates. Sterile discs $(6 \mathrm{~mm}$ diameter $)$ were impregnated with pervious solution of each compound, left to dry and were then placed on the surface of inoculated plates. Disc of antimicrobial standard were put in the center of plate agar; these plates were incubated at $37^{\circ}$ for 24 hours. After incubation the plates were examined visually and the zones of inhibition were measured.

\section{RESULTS AND DISCUSSION}

2-Chloroquinoline-3-carbonitrile (II) was prepared by one-pot reaction via Vilsmeier formylation of acetanilide (I) using $\left(\mathrm{DMF} / \mathrm{POCl}_{3}\right)^{20}$ followed by treating with hydroxylamine hydrochloride whereby $44 \%$ yield of (II) was obtained. 2-Chloro-quinoline3-carbonitrile (II) was condensed with a variety of aliphatic and aromatic amines in dioxane, whereby several new 2-substituted aminoquinoline-3-carbonitriles (III) were obtained. The structures of (III) were confirmed by elemental analysis and spectral data obtained from IR, NMR and mass spectra. The IR spectra of compounds (III) in $\mathrm{KBr}$ are characterized by strong absorption band at about $3386 \mathrm{~cm}^{-1}$ (due $\mathrm{N}-\mathrm{H}$ stretching) and a sharp intense band around $2229 \mathrm{~cm}^{-1}$ (due to $\mathrm{C} \equiv \mathrm{N}$ stretching). The ${ }^{1} \mathrm{HNMR}$ spectra of (III) are characterized by the presence of a broad singlet of one proton at about $5.32 \mathrm{ppm}$ (due to the NH in case of aliphatic substitution). This signal appeared around $7.5 \mathrm{ppm}$ in case of aryl substitution. The aromatic protons of the quinoline nucleus displayed a triplet of one proton at 7.30-7.22 (H-6), a multiplet of three protons at 7.75-7.56 ppm ( $\mathrm{H}-7, \mathrm{H}-5$ and $\mathrm{H}-8)$, and a singlet of one proton at $8.18 \mathrm{ppm}(\mathrm{H}-4)$. The EI mass spectra of compounds (III) show prominent molecular ion peak, which might represent the base peak. Loss of ${ }^{\cdot} \mathrm{H},{ }^{\circ} \mathrm{CN}, \mathrm{HCN}$ and the 2-substituent from the molecular ion was observed. 
In addition, 2-chloroquinoline-3carbonitrile (II) was treated with thiourea in the presence of sodium hydroxide to give 2thioquinoline-3-carbonitrile (IV) ${ }^{21}$ which was treated with potassium hydroxide in absolute ethanol to give the corresponding potassium salt $(\mathbf{V})$. Condensation of $(\mathbf{V})$ with different alkyl and aryl chloroacetates afforded the desired 3-cyano-2-alkoxy / aryloxycarbonylmethylthioquinolines (VI). The structures of (VI) were also confirmed by elemental and spectral analysis. The IR spectra of (VI) in $\mathrm{KBr}$ are characterized by sharp intense peak around $1730 \mathrm{~cm}^{-1}$ (due to $\mathrm{C}=\mathrm{O}$ stretching) and another peak at $2223 \mathrm{~cm}^{-1}$ (due to $\mathrm{C} \equiv \mathrm{N}$ stretching). The ${ }^{1}$ HNMR spectra of (VI) are characterized by the presence of a singlet of two protons at about $4.15 \mathrm{ppm}$ (due to $-\mathrm{S}-\underline{\mathrm{CH}}_{2}-\mathrm{CO}$ ). The EI mass spectra of compounds (VI) showed prominent molecular ion peaks. The fragmentation patterns of these compounds are characterized by loss of the alkoxy or aryloxy group, which might produce the base peak. Loss of $\mathrm{CO}, 2$-substituent and $\mathrm{CN}$ or $\mathrm{HCN}$ is also observed.

Moreover, 2-chloroquinoline-3-carbonitrile (II) was allowed to react with hydrazine in absolute ethanol at the reflux temperature for 24 hours whereby $1 \mathrm{H}$-pyrazolo[3,4-b]quinolin3 -amine (VII) in $60 \%$ yield. ${ }^{16}$ An alternative method was tried to obtain (VII) in a short time with an improved yield. This method involved reaction of hydrazine hydrate with 2mercaptoquinoline (IV) in refluxing ethanol for 12 hours whereupon 1H-Pyrazolo[3,4b]quinolin-3-ylamine (VII) was obtained in $75 \%$ yield. The later (VII) was allowed to condense with different aromatic aldehydes whereby some new Schiff's bases (VIII) were obtained. The structures of compounds (VIII) were confirmed by elemental and spectral analysis. The ${ }^{1}$ HNMR spectra of (VIII) revealed a downfield singlet of one proton at about $13.37 \mathrm{ppm}$, disappeared on equilibration with $\mathrm{D}_{2} \mathrm{O}$ (pyrazolo $\mathrm{NH}$ ), a singlet of one proton at $9.21 \quad \mathrm{ppm} \quad\left(-\mathrm{N}=\mathrm{CH}-\underline{H}^{-} . \quad\right.$ The characteristic pattern of quinoline protons appeared in the region of 9.29-7.52 ppm. It is important to indicate that fusion of the pyrazole ring bearing an imine function at position-3 with a quinoline nucleus led to downfield shift of the H-4 signal of quinoline ring by about 1 ppm. The EI spectra of (VIII) are characterized by distinct molecular ion peaks. The spectra are characterized by the presence of common peaks at $\mathrm{m} / \mathrm{z}$ 184(due to cleavage of azomethine double bond and abstraction of two hydrogen atoms), 169 (due to loss of the 3-substituent moiety) and 142 (aziridinoquinoline radical cation).

Furthermore, 1H-pyrazolo[3,4-b]quinolin3 -amine (VII) was allowed to react with $p$ chlorobenzoyl chloride to give 4-chloro- $\mathrm{N}-(1 \mathrm{H}-$ pyrazolo-[3,4-b]quinolin-3-yl)-benzamide (IX). Its ${ }^{1} \mathrm{HNMR}$ of (IX) in DMSO revealed two downfield singlets each of one proton around 13.00 and $11.00 \mathrm{ppm}$ disappeared on deuteration. These are due to $\mathrm{NH}$ of pyrazole ring and the amidic $\mathrm{NH}$ respectively.

The data obtained from the preliminary antimicrobial testing of the newly synthesized compounds using the agar diffusion method ${ }^{19}$ and presented in (Table (4) reveals that some 2substituted aminoquinoline-3-carbonitriles (IIIa-IIIc) showed a moderate antibacterial activity against $S$. aureus and weak activity against B. subtilis. Compounds (III) were found to be inactive against $E$. coli, $P$. aeruginosa and $C$. albicans. The 2alkoxycarbonylmethylthioquinoline-3-

carbonitriles (VI) showed a moderate activity against $S$. aureus and E. coli. They exhibited a weak to moderate antifungal activity against $C$. albicans. The compounds are ineffective against $P$. aeruginosa. The arylidenepyrazoloquinolines (VIII) were found to possess a weak to moderate antifungal activity against $C$. albicans. Some of such derivatives are only effective E. coli. 
Table 4: Antimicrobial Testing of the newly synthesized compounds, Ofloxacin and Nystatin.

\begin{tabular}{|c|c|c|c|c|c|}
\hline \multirow{2}{*}{$\begin{array}{l}\text { Comp. } \\
\text { No. }\end{array}$} & \multicolumn{5}{|c|}{ Microorganism (Inhibition Zone) } \\
\hline & $\begin{array}{c}\text { Staphylococcus } \\
\text { aureus }\end{array}$ & $\begin{array}{r}\text { Basillus } \\
\text { subtilis }\end{array}$ & $\begin{array}{c}\text { Escherichia } \\
\text { coli }\end{array}$ & $\begin{array}{l}\text { Pseudomonas } \\
\text { aeruginosa }\end{array}$ & $\begin{array}{l}\text { Candida } \\
\text { albicans }\end{array}$ \\
\hline IIIa & $16 \mathrm{~mm}$ & $4 \mathrm{~mm}$ & -- & -- & -- \\
\hline IIIb & $15 \mathrm{~mm}$ & $2 \mathrm{~mm}$ & -- & -- & -- \\
\hline IIIc & $15 \mathrm{~mm}$ & $2 \mathrm{~mm}$ & -- & -- & -- \\
\hline IIId & -- & $2 \mathrm{~mm}$ & -- & -- & -- \\
\hline IIIe & -- & -- & -- & -- & -- \\
\hline IIIf & -- & -- & -- & -- & -- \\
\hline VIa & $15 \mathrm{~mm}$ & - & $4 \mathrm{~mm}$ & - & $2 \mathrm{~mm}$ \\
\hline VIb & $12 \mathrm{~mm}$ & - & $6 \mathrm{~mm}$ & -- & $4 \mathrm{~mm}$ \\
\hline VIc & $10 \mathrm{~mm}$ & - & $8 \mathrm{~mm}$ & - & $4 \mathrm{~mm}$ \\
\hline VId & $10 \mathrm{~mm}$ & $12 \mathrm{~mm}$ & $9 \mathrm{~mm}$ & - & $11 \mathrm{~mm}$ \\
\hline VIe & $10 \mathrm{~mm}$ & $10 \mathrm{~mm}$ & $8 \mathrm{~mm}$ & -- & $10 \mathrm{~mm}$ \\
\hline VIIIa & -- & -- & -- & - & $5 \mathrm{~mm}$ \\
\hline VIIIb & -- & -- & -- & -- & $8 \mathrm{~mm}$ \\
\hline VIIIc & -- & -- & -- & -- & $10 \mathrm{~mm}$ \\
\hline VIIId & -- & -- & $8 \mathrm{~mm}$ & -- & $12 \mathrm{~mm}$ \\
\hline VIIIe & -- & -- & $6 \mathrm{~mm}$ & $4 \mathrm{~mm}$ & $8 \mathrm{~mm}$ \\
\hline IX & $10 \mathrm{~mm}$ & $2 \mathrm{~mm}$ & $10 \mathrm{~mm}$ & -- & -- \\
\hline Ofloxacin & $20 \mathrm{~mm}$ & $20 \mathrm{~mm}$ & $15 \mathrm{~mm}$ & $30 \mathrm{~mm}$ & -- \\
\hline Nystatin & -- & -- & -- & -- & $20 \mathrm{~mm}$ \\
\hline
\end{tabular}

\section{Acknowledgement}

The authors would like to thank Prof. Dr. M. Saif El-Deen Ashour, Professor and Head of Microbiology and to Mr. Mohamed Salah, Assistant Lecturer of Microbiology, Department of Microbiology, Faculty of Pharmacy, Al-Azhar University, Cairo, Egypt for their valuable help in performing the microbiological testing of the newly synthesized compounds.

\section{REFERENCES}

1- J. Hill, "Chemotherapy of Malaria, Part 2: The Antimalarial Drugs, In., Experimental Chemotherapy", Vol. 1, 1963, pp. 513560, (Schnitzer, R.J. and Hawking, F., eds.,) Academic Press Inc., New York.

2- P. H. Schlesinger, D. J. Krogstad and B. L. Herwaldt, Antimicrob. Agents Chemother., 32, 793-798 (1988).

3- H. H. van Es, E. Skamene and E. Schurr, Clin. Invest. Med., 16, 285-293 (1993).

4- J. R. Zucker and C. C. Campbell, Infect. Dis. Clinic North Am., 7, 547-567 (1993).
5- W. O. Foye, T. L. Lemke and D. A. Williams, "Principles of Medicinal chemistry", $4^{\text {th }}$ Ed. Alea \& Febiger Book (Williams and Wilkins) Philadelphia, London, Tokyo, (1995), p. 740.

6- J. W. Tracy and L. T. Jr. Webster, "Drugs used in the Chemotherapy of Protozoal Infections" In, "Goodman \& Gilman's The Pharmacological Basis of Therapeutics", $9^{\text {th }}$ Ed., McGraw-Hill, New York, London, (1996), p. 993.

7- Anon, Neth. Pat., 6,601,980 (1966), through Chem. Abstr., 66, 115616k (1967).

8- S. Yoshizaki, K. Tanimura, S. Tamada, Y. Yabuuchi and Nakagawa, J. Med. Chem., 19, 1138 (1976).

9- F. F. Ebetino and G. C. Wright, French Pat., 1,388,756 (1965), through Chem. Abstr., 63, 589c (1965).

10- M. Ishikawa, A. Sugimoto, S. Ito, H. Azuma, SW. Moriguchi and H. Ebisawa, Jpn. Kokai, Tokkyo Koho J. Pat,, 85,178,866 (1985), through Chem, Abstr., 104, 68764y (1986). 
11- J. M. McCall, U.S. Pat., 4,167,567 (1979), through Chem. Abstr. 92, 6555f (1980).

12- D. Lednicer, and L. A. Metscher, "The Organic Chemistry of Drug Synthesis", Wiley, New York, Vol. 1, 1977 p. 242, and Vol. 3, 1984, p. 184.

13- R. Rodriquez, German Pat., 2,006,638 (1970), through Chem.. Abstr., 73, 98987g (1970).

14- D. H. Boschelli, Y. D. Wang, F. Biqiwu, N. Zhang, M. Dutia, D.W. Powell, A. Wissner, K. Arndt, J. M. Weber and F. Boschelli, J. Med. Chem., 44, 822 (2001).

15- S. Radl, V. Zikan and F. Smejkal, Cesk. Farm, 34, 119, (1985) through Chem. Abstr., 104, 109528v (1986), idem 34, 383, (1985) through Chem. Abstr., 105, 226434t (1986) and S. Radl, V. Zikan and F. Smejkal, ibid 35, 119 (1986) through Chem. Abstr., 106, 18429 p (1987).
16- M. R. Bell and J. H. Ackerman, U.S. Pat.., 4,920,128 (1990).

17- T. L. Wright, U.S. Pat., 4,540,786 (1985).

18- O. Meth-Cohn, B. Narine and B. Tarnowski, J. Chem., Soc., Perkin Trans I, 1520-1536 (1981) \& O. Meth-Cohn, S. Rhouati, B. Tarnowski, and A. Robinson, ibid., 1537-1542 (1981).

19- W. Hewth, and S. Vincent, "Theory and Application of Microbiological Assay", Academic Press 1NC, New York (1989).

20- J. S. Pizey, "Synthetic Reagents", Vol. 1, 1-99, Wiley, New York (1974).

21- E. A-G. Bakhite, Collect Czech. Chem. Commun., 57, 2359 (1992).

22- O. A. El-Sayed, F. M. El-Bieh, B. A. AlBassam and M. E. Hussein, Boll. Chim. Farmac.- Anno 141 (6), (2002).

23- O. A. El-Sayed and H. Y. Aboul-Enein, Arch. Pharm. Med. Chem. Weinheim, 334, 117-120 (2001). 